\title{
Evidence of ERalpha and ERbeta selectivity and partial estrogen agonism in traditional Chinese medicine
}

Dov Tiosano ${ }^{1 \dagger}$, Françoise Paris ${ }^{2,3,4+}$, Marina Grimaldi ${ }^{4}$, Vera Georgescu ${ }^{6}$, Nadège Servant ${ }^{3}$, Zeev Hochberg ${ }^{1,5}$, Patrick Balaguer ${ }^{4}$ and Charles Sultan $2,3^{*}$

\begin{abstract}
The use of complementary and alternative medicine and herbal products, especially traditional Chinese medicines, is progressively rising for both adults and children. This increased use is based on the popular belief that these medicines are safe and harmless. In this report, we describe the results of a bedside-to-bench study that involved a short-statured 4-year-old boy with deficiencies in growth hormone, thyroid stimulating hormone, and adrenocorticotropic hormone due to an ectopic posterior pituitary gland and invisible pituitary stalk. Although the boy was given replacement therapy with hydrocortisone and L-thyroxin, the parents refused to treat him with growth hormone and consulted a naturopath who prescribed a traditional Chinese medicine (TCM) to stimulate the boy's growth. From the age of 20 months, the child's growth was regularly monitored while he was being treated with hydrocortisone, thyroxin, and the TCM. Over a 36-month period, the child's growth velocity accelerated $(3 \mathrm{~cm} /$ year to $8 \mathrm{~cm} /$ year), his height increment substantially increased (-2 SD to $-0.8 \mathrm{SD}$ ), and his bones matured. In the laboratory investigation, estrogen receptor (ER)alpha and ERbeta reporter cell lines were used to characterize the estrogenic activity of the TCM medicine and its 18 components, and the results established that the medicine and some of its components have estrogen receptor ERalpha and ERbeta selectivity and partial estrogen agonism. Partial estrogenic activity of the TCM was confirmed using whole-cell competitive binding, cell proliferation, and endogenous gene expression assays in the ERalpha-positive breast cancer cell lines. Although the presence of evidence is not always evidence of causality, we have concluded that this traditional Chinese medicine contains ingredients with estrogenic activity that can sustain bone growth and maturation without affecting other estrogen-dependent tissues.
\end{abstract}

Keywords: Estrogen receptors, Traditional Chinese medicines

\section{Background}

Over the past few decades, the use of traditional Chinese medicines (TCMs) has become internationalized. Although most components in TCMs are derived from plants, some are also derived from animals. Irrespective of the source of their components, TCMs are generally perceived as being safe and easy to use [1-5].

\footnotetext{
*Correspondence: c-sultan@chu-montpellier.fr

${ }^{\dagger}$ Equal contributors

2Unité d'Endocrinologie Pédiatrique, CHU Arnaud de Villeneuve, Montpellier, France

${ }^{3}$ Département d'Hormonologie, CHU Lapeyronie, et Université Montpellier 1, Montpellier, France

Full list of author information is available at the end of the article
}

Our interest in TCMs and their possible effect on growth began when a short-statured 4-year-old boy with multiple pituitary hormone deficiencies, whose parents refused to treat him with growth hormone, exhibited unexpected growth acceleration and rapid bone maturation without any untoward effects on the development of his breast and genitals. On questioning, the boy's parents informed us that he was also being treated with a TCM which had been prescribed by a naturopath. This TCM comprised 18 different components, of which 16 were derived from plants.

Many plants have been identified as containing phytoestrogens, some of which have also been classified as selective ER modulators (SERMs) because they have 
been shown to inhibit or stimulate estrogen-like actions in a cell-type, tissue-specific, and dose-dependent manner [6]. We therefore hypothesized that the growth acceleration and bone-age advancement in our patient was due to the presence of phytoestrogens in the TCM, and that these phytoestrogens were acting as SERMs.

It is now well known that the human estrogen receptor (ER) exists as two subtypes, ER $\alpha$ and $E R \beta$, and that the two subtypes are expressed in the human growth plate. Both subtypes are ligand-inducible transcription factors, and their activities are regulated by $17 \beta$-estradiol $\left(E_{2}\right)$, which is important for the growth and maintenance of a diverse range of tissues, such as the mammary gland, uterus, and bone, and physiological systems like the cardiovascular and central nervous systems. Specifically, estrogens have a well-defined critical role in bone maturation and longitudinal bone growth in boys and girls $[7,8]$, and clinical observations have confirmed the role of estrogens in regulating longitudinal bone growth and growth plate closure. Low estradiol levels were shown to enhance skeletal growth during early sexual maturation (the pubertal growth spurt), while high $\mathrm{E}_{2}$ levels during late puberty accelerated growth plate fusion and the cessation of longitudinal bone growth $[7,9]$. In the absence of estrogens, as found in females and males with a mutation of the aromatase gene or in the presence of a mutation of the ER $\alpha$ gene, the duration of the pubertal growth spurt is prolonged and the affected individuals continue to grow slowly after sexual maturation because the growth plates do not fuse $[8,10,11]$. Furthermore, in some patients with growth hormone deficiency and advanced puberty, the pubertal growth spurt is observed, suggesting that estrogens may act directly on growth plate chondrocytes [12].

The effect of estrogens on target tissues depends on the balance between ER $\alpha$ and ER $\beta$ signaling [13] and, in phytoestrogens, on the varying degrees of selectivity for $E R \alpha$ and ER $\beta$ [14]. The expression of ER $\alpha$ and ER $\beta$ in the human growth plate, with no difference in the expression pattern over the course of puberty or between sexes, reinforces the idea that estrogens can influence growth plate chondrocytes [15].

It is known that ER contains two distinct and independent transcriptional activation functions, AF-1 and AF-2 [16]. The activity of AF-1, which is located at the $\mathrm{N}$-terminal $\mathrm{A} / \mathrm{B}$ region of the receptor, is constitutive, whereas the activity of AF-2, which is located at the $\mathrm{COOH}$ terminus in the hormone-binding domain, is estrogen-inducible. Full transcriptional activity of the ER is achieved through synergism between its AFs [17]. It has also been reported that AF-1 possesses strong ligandindependent activity in some cell types and on some promoters and that the partial agonist activity of the ER can be modulated by the activity of AF-1 [18]. The amino acids (aa) that are important for AF-1 activity are found in segments between aa 41 and 120-150 at the $\mathrm{N}$-terminal A/B region of the receptor [19]. The molecular mechanism of estrogen action on growth plate closure has recently been clarified. Growth plate closure only occurs in mice following specific inactivation of AF-1 in the ER $\alpha$. This finding indicates that growth plate closure is induced by functions of the $\mathrm{ER} \alpha$ that do not require AF-1 and that ER $\alpha$ AF-1 opposes growth plate closure [20]. The role of ER $\beta$ in growth plate cartilage seems more questionable in males [21] since knocking out ER $\beta$ in male mice does not influence bone growth at any stage of their development [22-24].

In order to test our hypothesis, we undertook a study to determine whether any of the 18 components in the TCM possess ER $\alpha$ or ER $\beta$ activity. To this end, we determined the estrogenic potencies of the TCM and each of the 18 components using estrogen-responsive element (ERE)-based luciferase reporter ER $\alpha$ and the ER $\beta$ assays. Furthermore, we confirmed that the TCM had estrogenic activity using binding assays, endogenous $\mathrm{E}_{2}$-regulated genes expression and E2-regulated proliferation assays in an ER $\alpha$ - positive breast cancer MCF-7 cell line.

\section{Case report}

The boy was born after an uneventful pregnancy at 37 weeks gestation with a birth weight of 2,910 grams and is the first child of healthy non-consanguineous parents. The clinical examination at birth revealed a severe micropenis $(1 \mathrm{~cm},<2.5$ SDS) and bilateral undescended testes, and the results of clinical endocrinology examination revealed signs of neonatal hypoglycemia, central hypothyroidism, and growth hormone (GH) and adrenocorticotrophic hormone (ACTH) deficiencies (Table 1). Replacement therapy with hydrocortisone $\left(8 \mathrm{mg} / \mathrm{m}^{2} \mathrm{BSA}\right)$ and $50 \mu \mathrm{g} /$ day L-thyroxin was initiated. The bone age of the child before the start of replacement therapy was 3 years and the results of a brain magnetic resonance imaging (MRI) study revealed an ectopic posterior pituitary gland and an invisible pituitary stalk. The parents refused the recommended $\mathrm{GH}$ replacement therapy and consulted a naturopath, who prescribed a TCM with 18 components, of which 16 were of plant origin and two were of animal origin (Table 2). In addition to the hydrocortisone and thyroxin, the child was treated with the TCM (2-4 mls/day per os) for 36 months, during which his growth was regularly monitored. Over this 36-month period, his growth velocity accelerated ( $3 \mathrm{~cm} /$ year to $8 \mathrm{~cm} /$ year), his SD score for height substantially increased ( -2 to -0.8$)$, and his bone age advanced to 7 years. No changes were noted in the development of his breasts or genitals. 
Table 1 Results of endocrine evaluation in the neonatal period and the growth hormone axis at different ages Neonatal period Basal Stimulated / ACTH

Cortisol $(\mathrm{nmol} / \mathrm{l})$
TSH $(\mathrm{mU} / \mathrm{l})$
T4 $(\mu \mathrm{g} / \mathrm{dl})$
$\mathrm{GH}(\mu \mathrm{U} / \mathrm{ml})$ during hypoglycemia

20 Months

$$
\begin{gathered}
20(N>300) \\
5(N: 0.7-15) \\
4(N>5) \\
8.2(N>20)
\end{gathered}
$$

/ Arginine

2.4

$30^{\prime}: 2.8(N>20)$

$60^{\prime} 3$

$90^{\prime} 2.8$

$120^{\prime} 1.8$

IGF1 (nmol/l)

\section{Months}

IGF1 (nmol/l 16 (N:5.7-26.4)

$X^{\prime}$ : time in minutes.

/ ACTH" serum cortisol level after stimulation testing with ACTH after 60 minutes.

TSH: thyroid-stimulating hormone.

TT4: total thyroxine.

\begin{tabular}{|c|c|c|c|}
\hline Botanical, zoological or pharmaceutical name & Pinyin transliteration & Amount in medicine (grams) & Identification code \\
\hline Polygonatum sibiricum Redoute & huang jing & 5 & A \\
\hline Astragalus membranaceus (Fisch.) Bge & huang qi & 5 & B \\
\hline Drynaria fortunei (Kunz) J. Sm & gu sui bu & 5 & C \\
\hline Boswellia carterii Birdw. & ru xiang & 5 & $\mathrm{D}$ \\
\hline Cervus nippon Temmiinck & lu rong & 5 & $\mathrm{E}$ \\
\hline Gallus gallus domesticus Brisson & ji nei jin & 5 & $\mathrm{~F}$ \\
\hline Morinda officinalis How & bai ji li & 5 & G \\
\hline Ophiopogon japonicus Ker-Gawl & mai men dong & 5 & $\mathrm{H}$ \\
\hline Commiphora myrrha Engl. & mo yao & 5 & 1 \\
\hline Rehmannia glutinosa (Gaertn.) Libosch & shu di & 5 & J \\
\hline Dioscorea opposita Thunb. & shan yao & 6 & K \\
\hline Cornus officinalis Sieb. et Zucc. & shan zhu yu & 5 & L \\
\hline Bupleurum chinense D.C. & chai hu & 4 & M \\
\hline Alisma plantago-aquatica L.var. orientale Samuels & ze xie & 3 & $\mathrm{~N}$ \\
\hline Massa Ferentata Medicinalis & shen qu & 2 & $\mathrm{O}$ \\
\hline Glycyrrhiza uralensis Fischer & gan cao & 10 & P \\
\hline Poria cocos (Schw.) Wolf & fu ling & 5 & Q \\
\hline Citrus reticulata Blanco & chen pi & 5 & $\mathrm{R}$ \\
\hline
\end{tabular}

/ Arginine: serum GH level after stimulation testing with arginine.

IGF-1: insulin-like growth factor 1 .

Table 2 The 18 components of the traditional Chinese medicine

Sixteen of the components are of plant origin and two of the components, lu rong (E) and ji nei jin (F) are of animal origin. Massa fermenta medicinalis (O) is a non-standardized mixture of a fermented preparation of wheat flour and bran and the fresh aerial parts of medicinal herbs that may include xanthium, apricot kernel, artemesia, polygonum, and phaseolus. 


\section{Methods}

\section{Chemicals, reagents, and preparation of tinctures}

Dulbecco's modified Eagle medium: Nutrient Mixture F12 (DMEM F12), fetal calf serum (FCS) and geneticin, were purchased from Life Technologies Inc., Cergy-Pontoise, France. Luciferin was purchased from Promega, Charbonnières, France. $E_{2}$, genistein, ferutinin, puromycin, and 3-[4,5dimethyliazol-2-yl]-2,5-diphenyltetrazolium bromide (MTT) were purchased from Sigma-Aldrich, Inc., St. Louis, MO, USA.

Ethanol tinctures (35\%) of each component in the TCM (A-R) (Table 2) were prepared in the following manner. After weighing, each component was first minced with a surgical scalpel and then dissolved in $70 \%$ ethanol: $30 \%$ sterile water at a solvent to plant ratio of $3: 1(\mathrm{v} / \mathrm{w})$. Each solution was then steeped at room temperature for 3 weeks on a horizontal agitator, and then filtered through sterilized tulle. The filtrate was then diluted in sterile water at a ratio of $2: 1(\mathrm{v} / \mathrm{v})$ in order to obtain a $35 \%$ ethanol tincture.

Stock solutions (10 $\mathrm{nM}$ in DMSO) of $\mathrm{E}_{2}$, genistein, and ferutinin were stored at $-20^{\circ} \mathrm{C}$. The TCM and the 18 tinctures were stored at $4^{\circ} \mathrm{C}$. Before each assay, the stock solutions, the TCM, and the 18 tinctures were serially diluted using culture medium.

\section{Determination of ER Activity of the herbal medicine and its components}

ERE-luciferase reporter assays were done in reporter HELN-ER cell lines [25] to investigate whether the TCM and any of its components have ER activity. Briefly, these cells were generated in two steps. The estrogen-responsive reporter gene was first stably transfected into HeLa cells, generating HELN cell line (named HELN for HeLaERE-Luciferase-Neo) and, in a second step, these HELN cells were transfected with $E R \alpha$ (amino acids 1-595), $\triangle \mathrm{A} / \mathrm{B}$ deleted domain $\mathrm{ER} \alpha(\Delta \mathrm{A} / \mathrm{B}-\mathrm{ER} \alpha$ and amino acids 179-595), ER $\beta$ (amino acids 1-530) and $\Delta \mathrm{A} / \mathrm{B}-\mathrm{ER} \beta$ (amino acids 143-530) plasmid constructs to obtain the HELN-ER $\alpha,-\triangle \mathrm{A} / \mathrm{B}-\mathrm{ER} \alpha,-\mathrm{ER} \beta$, and $-\Delta \mathrm{A} / \mathrm{B}-\mathrm{ER} \beta$ cell lines, respectively.

The HELN-ER cells were cultured in DMEM F12 without red phenol, which was supplemented with 5\% dextran-coated charcoal-treated FCS (DCC-FCS), 1\% antibiotic, $1 \mathrm{mg} / \mathrm{ml} \mathrm{G} 418$, and $0.5 \mu \mathrm{g} / \mathrm{ml}$ puromycin in a $5 \% \mathrm{CO}_{2}$ humidified atmosphere at $37^{\circ} \mathrm{C}$. For all assays, the HELN cells were cultured in DMEM, which was supplemented with 5\% FCS and 1\% antibiotic, in a 5\% $\mathrm{CO}_{2}$ humidified atmosphere at $37^{\circ} \mathrm{C}$.

The TCM and its 18 components were first tested for non-specific modulation of luciferase expression on the HELN parental cell line, which contains the same reporter gene as HELN-ER cells but is devoid of ER. Except for component $\mathrm{P}$, no toxicity or non-specific modulation was observed at concentrations lower than $1 \%$. Then, the TCM and its components were tested for their ER activity. For this purpose, HELN and HELN-ER reporter cells $\left(5 \times 10^{4}\right.$ cells/well) were seeded into a 96-well white opaque tissue culture plate (Greiner reference 655083). Eight hours after seeding, the cells were then exposed for 16 hours at $37^{\circ} \mathrm{C}$ to serial dilutions of the TCM and its 18 components (1\% to $0.0001 \%$ of the methanol extract). At the end of the 16-hour incubation, the medium that contained the TCM or the tinctures was removed and replaced by test culture medium that contained $0.3 \mathrm{mM}$ luciferin. At this concentration, luciferin diffuses into the cells, which generate a "glow-type" luminescent signal that is very stable for several hours. This luminescence was measured for 2 seconds in a MicroBeta Trilux luminometer (EGG Wallac, Turku, Finland). All assays at each concentration or dilution were done in quadruplicate, and three experiments were done in order to establish the response curves. The results are expressed as a percentage of maximum luciferase activity (100\%), which was obtained in the presence of $10 \mathrm{nM} \mathrm{E}_{2}$. In order to obtain an indirect measure of the affinity for ERs of the TCM and its 18 components, the estrogenic potency or the concentration that yielded the half-maximal luciferase activity $\left(\mathrm{EC}_{50}\right)$ of the TCM and its 18 components was determined.

\section{Whole-cell ERa and ER $\beta$ competitive binding assays}

HELN-ER $\alpha$ and HELN-ER $\beta$ cells were seeded into each well $\left(7 \times 10^{4}\right.$ cells/well $)$ of a 96-well white opaque tissue culture plate with a clear bottom (Greiner reference 655098) and grown in the test culture medium for 24 hours in a $5 \% \mathrm{CO}_{2}$ humidified atmosphere. At the end of the 24 hours, the cells were exposed to increasing dilutions of the TCM (1-0.0003\%) in the presence of $0.3 \mathrm{nM}\left[{ }^{3} \mathrm{H}\right]-\mathrm{E}_{2}(41.3 \mathrm{Ci} / \mathrm{mmol}$ specific activity) for 3 hours at $37^{\circ} \mathrm{C}$. At the end of the incubation, the liquid in each well was aspirated and the cells were washed three times with $100 \mu \mathrm{l}$ of cold phosphate buffered saline (PBS). Scintillation fluid $(50 \mu \mathrm{l})$ (LS-6000-SC, Beckman-Coulter, Roissy, France) was added to each well, and the amount of $\left[{ }^{3} \mathrm{H}\right]$-bound radioactivity in the mixture was determined using the MicroBeta Trilux luminometer (EGG Wallac, Turku, Finland). Non-specific binding was determined in the presence of $100 \mathrm{nM}$ unlabeled $\mathrm{E}_{2}$. Specific binding was calculated by subtracting non-specific binding from total binding and was expressed as a percentage of the maximum ER binding (100\%), which was obtained in absence of the herbal medicine. The $\mathrm{IC}_{50}$ value was defined as the dilution at which $\left[{ }^{3} \mathrm{H}\right]-\mathrm{E}_{2}$ binding was $50 \%$. Determinations were made in quadruplicate in three separate experiments. The absence of toxicity was determined by visual inspection. 
MCF-7 cell proliferation assay

MCF-7 cells were seeded into each well $\left(10^{3}\right.$ cells/well $)$ of a 96-well culture plate and grown in the test culture medium for 24 hours at $37^{\circ} \mathrm{C}$. After 24 hours, the cells were exposed for 6 days at $37^{\circ} \mathrm{C}$ in a $5 \% \mathrm{CO}_{2}$ humidified atmosphere to increasing concentrations of $\mathrm{E}_{2}\left(10^{-12}-10^{-9} \mathrm{M}\right)$ and increasing dilutions of the TCM (1-0.001\%). At the end of the incubation period, the medium in each well was removed and replaced by $100 \mu \mathrm{l}$ of test culture medium that contained $0.5 \mathrm{mg} / \mathrm{ml} \mathrm{3-(4,5-methylthiazol-2yl)-2,5-}$ diphenyltetrazolium bromide (MTT). At the end of a 4hour incubation at $37^{\circ} \mathrm{C}$, the MTT-formazan-containing
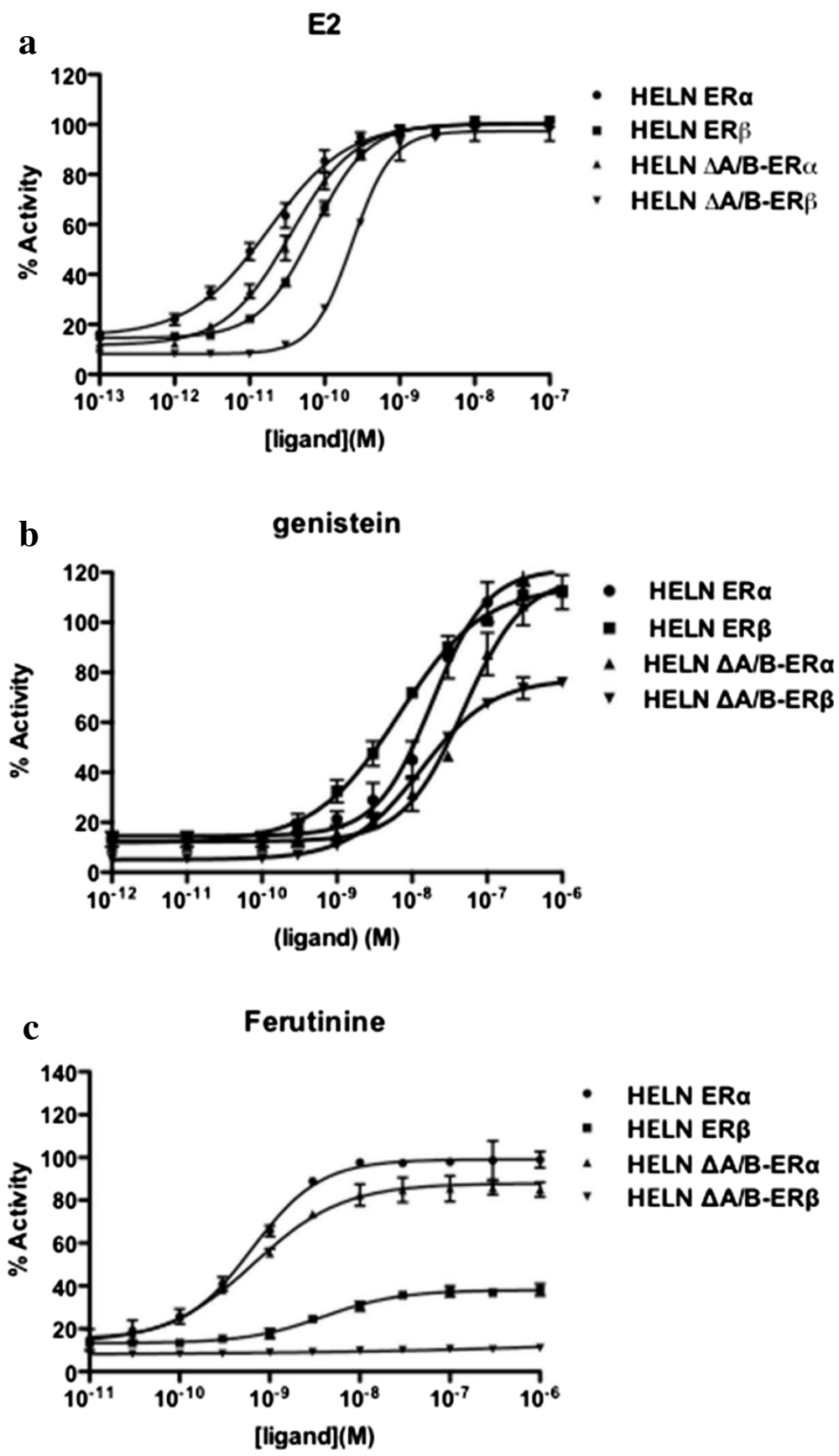

Figure 1 The concentration-response curves to $E_{2}(\mathbf{a})$, genistein (b), and ferutinin (c). The curves were constructed by exposing HELN-ERa (ERa), HELN-ERß (ERß), HELN- $\triangle \mathrm{A} / B E R a(\triangle A B-E R a)$, and HELN- $\triangle A / B E R \beta$ ( $\triangle A B-E R \beta)$ cells to increasing concentrations of $E_{2}$, genistein, and ferutinin for 16 hours at $37^{\circ} \mathrm{C}$ in a $5 \% \mathrm{CO}_{2}$ humidified atmosphere. The results are expressed as a percentage of maximum luciferase activity (100\%), which was determined when the cells were exposed to $10^{-8} \mathrm{M} \mathrm{E}_{2}$. Each value at each concentration in the response curves is the mean \pm standard deviation from three separate experiments. 
Table $3 \mathrm{EC}_{50}$ of $17 \beta$ estradiol $\left(\mathrm{E}_{2}\right)$; the phyotoestogen, genistein; the sesquiterpenoid, ferutinin; the traditional Chinese medicine (TCM); and the six selected components of the herbal medicine that were determined in the HELN-ERa, HELN-ER $\beta, H E L N-\triangle A / B E R a$, and HELN- $\triangle A / B E R \beta$ cell lines

\begin{tabular}{|c|c|c|c|c|c|}
\hline & ERa & $\Delta \mathrm{A} / \mathrm{BERa}$ & $E R \beta$ & $\Delta \mathrm{A} / \mathrm{BER} \beta$ & $\begin{array}{c}\text { ERa vs ER } \beta \\
p \text {-value }\end{array}$ \\
\hline \multicolumn{6}{|c|}{$E C_{50}(n M)$} \\
\hline$E_{2}$ & 0.017 & 0.034 & 0.068 & 0.22 & \\
\hline Genistein & 18.8 & 49.4 & 6.1 & 18.8 & \\
\hline Ferutinin & 0.64 & 0.65 & 3.9 & & \\
\hline \multicolumn{6}{|c|}{$E C_{50}(\%)$} \\
\hline Traditional Chinese medicine & 0.035 & 0.055 & 0.015 & 0.035 & 0.015 \\
\hline B & 0.2 & 0.25 & 0.055 & 0.15 & 0.003 \\
\hline $\mathbf{F}$ & 0.2 & 0.2 & 0.03 & 0.1 & $<0.001$ \\
\hline J & 0.04 & 0.04 & 0.02 & 0.03 & NS \\
\hline L & 0.3 & 0.3 & 0.4 & 0.4 & NS \\
\hline $\mathbf{P}$ & 0.004 & 0.007 & 0.002 & 0.004 & NS \\
\hline $\mathbf{R}$ & 0.07 & 0.08 & 0.035 & 0.06 & NS \\
\hline
\end{tabular}

The $\mathrm{EC}_{50}$ values for $\mathrm{E}_{2}$, genistein, and ferutinin are expressed in $\mathrm{nM}$, whereas those of the TCM and the components are expressed as percentages and correspond to dilutions of the TCM or components ( $1 \%=100$-fold dilution). Significant p-values corresponding to Student's t-test are reported (NS: not significant at the $5 \%$ significance level).

medium was gently removed, and the remaining MTTformazan crystals were dissolved by adding $100 \mu \mathrm{l}$ DMSO. After shaking, the cell number in each well was determined from the absorbance of the solution, which was measured with a microplate spectrophotometer at an absorbance of $540 \mathrm{~nm}$. Wells that contained only the test culture medium and MTT were used to blank the plate reader. Determinations were made in quadruplicate, and the data are expressed as the average absorbance of four wells at each concentration or dilution in three separate experiments. The results are expressed as a percentage of maximum luciferase activity (100\%), which was obtained the presence of $10 \mathrm{nM} \mathrm{E}_{2}$.

\section{E2-induced gene expression assays}

The effect of the TCM on endogenous estrogen-regulated gene expression was assessed by determining the mRNA levels of GREB1, pS2, RIP140, RAR $\alpha$ and PR in MCF-7 cells using RT-PCR. For this purpose, MCF-7 cells were treated for 24 hours with either $10 \mathrm{nM} \mathrm{E}_{2}$ or a $0.3 \%$ dilution of the TCM. At the end of the treatment, RNA was extracted from the cells using the RNeasy RNA isolation kit (Qiagen, Courtaboeuf, France). For RNA extractions,

Table 4 Maximal transcriptional activity of $17 \beta$ estradiol $\left(E_{2}\right)$; the phyotoestogen, genistein; the sesquiterpenoid, ferutinin; the traditional Chinese medicine (TCM); and the six selected components of the herbal medicine that were determined in the HELN-ERa, HELN-ER $\beta, H E L N-\triangle A / B E R a$, and HELN- $A$ A/BER $\beta$ cell lines

\begin{tabular}{|c|c|c|c|c|c|c|}
\hline & ERa & $\triangle \mathrm{A} / \mathrm{BERa}$ & ERa vs $\Delta \mathrm{A} / \mathrm{BERa}$ & $E R \beta$ & $\Delta \mathrm{A} / \mathrm{BER} \beta$ & $\operatorname{ER} \beta$ vs $\Delta A / B E R \beta$ \\
\hline & Max I & activity (\%) & p-value & Max I & activity (\%) & p-value \\
\hline$E_{2}$ & 100 & 100 & & 100 & 100 & \\
\hline Genistein & 121 & 117 & & 115.9 & 77.6 & \\
\hline Ferutinin & 99.1 & 87.9 & & 38.8 & 12 & \\
\hline Traditional Chinese medicine & 107.4 & 58 & 0.014 & 78 & 56 & $<0.001$ \\
\hline B & 80 & 39.6 & NS & 100 & 50 & 0.021 \\
\hline $\mathbf{F}$ & 94 & 57 & 0.002 & 86.5 & 53 & $<0.001$ \\
\hline J & 78 & 29 & NS & 61 & 35 & NS \\
\hline L & 69 & 23 & NS & 49 & 16 & NS \\
\hline $\mathbf{P}$ & 111 & 70 & 0.021 & 92 & 73 & NS \\
\hline $\mathbf{R}$ & 85 & 33 & 0.004 & 35 & 19 & NS \\
\hline
\end{tabular}

Significant p-values corresponding to Student's t-test are reported (NS: not significant at the 5\% significance level). 
two independent cultures were performed per condition. Reverse transcription was done on $1 \mu \mathrm{g}$ total RNA using random hexamers and SuperScript ${ }^{\mathrm{m}}$ II reverse transcriptase (Invitrogen) in a reaction solution which was diluted ten times for amplification. The mRNA levels of GREB1, pS2, RIP140, RAR $\alpha$, and PR were quantified by RT-PCR using SYBR $^{\circ}$ Green reagents in a LightCycler ${ }^{\circ}$ RT-PCR System (Roche SAS, Boulogne-Billancourt, France). The expression levels of each gene were normalized to that of the housekeeping $28 \mathrm{~S}$ gene, and quantified in relative units using qBase ${ }^{\text {PLUS }}$ [26]. Determinations were made in duplicate.

\section{Data analysis}

Data are reported as mean \pm standard deviation or standard error of the mean. The response curves were fitted and analyzed using the sigmoid dose-response function of a computerized graphics and statistics software package (Graph-Pad Prism, version 4.0, 2003, Graph-Pad Software Inc., San Diego, CA, USA).

The dose-response curves were fitted using a fourparameter log-logistic model. Statistical comparisons between parameters of fitted curves $\left(\mathrm{EC}_{50}\right.$ and maximal

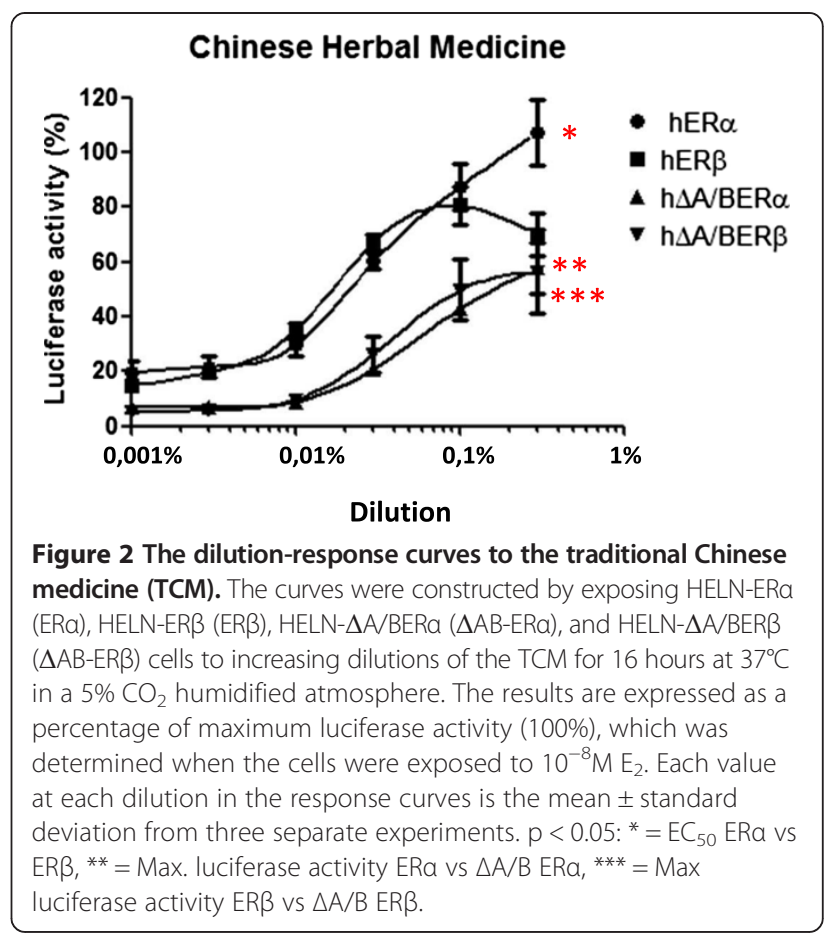

Table 5 The $\mathrm{EC}_{50}$ and maximal transcriptional activity of the traditional Chinese medicine (TCM) and its 18 components that were determined in the HELN-ERa and HELN-ER $\beta$ cell lines

\begin{tabular}{|c|c|c|c|c|c|}
\hline & & \multicolumn{2}{|l|}{ ERa } & \multicolumn{2}{|l|}{$E R \beta$} \\
\hline & & Max. luciferase activity \% & $\mathrm{EC}_{50} \%$ & Max. luciferase activity \% & $\mathrm{EC}_{50} \%$ \\
\hline Traditional Chinese medicine & & 107.4 & 0.035 & 78 & 0.015 \\
\hline Huang Jing & A & 48 & & 51 & \\
\hline Huang Qi & B & 80 & 0.2 & 100 & 0.055 \\
\hline Gu Sai Bu & C & 34 & & 23 & \\
\hline Ru Xiang & $\mathrm{D}$ & 38 & & 23 & \\
\hline Lu Rong & E & 74 & & 33 & \\
\hline Ji Nei Jin & $\mathrm{F}$ & 94 & 0.2 & 86.5 & 0.03 \\
\hline Bai Ji Li & G & 44 & & 33 & \\
\hline Mai Men Dong & $\mathrm{H}$ & 93 & & 38 & \\
\hline Mo Yao & 1 & 43 & 0.009 & 37 & 0.004 \\
\hline Shu Di & J & 78 & 0.04 & 61 & 0.02 \\
\hline Shan yao & K & 73 & & 45 & \\
\hline Shan Zu Yu & L & 69 & 0.3 & 49 & 0.4 \\
\hline Chai Hu & M & 57 & 0.1 & 43 & 0.1 \\
\hline Ze Xie & $\mathrm{N}$ & 33 & & 20 & \\
\hline Shen Qu & $\mathrm{O}$ & 100 & & 61 & \\
\hline Gan Cao & $P$ & 111 & 0.004 & 92 & 0.002 \\
\hline Fu Ling & Q & 108 & & 45 & \\
\hline Chen Pi & $\mathrm{R}$ & 85 & 0.07 & 35 & 0.035 \\
\hline
\end{tabular}

The $\mathrm{EC}_{50}$ values of the herbal medicine and the 18 components are expressed as percentages and correspond to dilutions of the TCM or component $(1 \%=100$-fold dilution). The percentage of maximum luciferase activity (100\%) was determined when the cells were exposed to $10^{-8} \mathrm{M} \mathrm{E}_{2}$. The complete identification code of the 18 herbal components is explained in Table 2. 
activity) were performed with the drc package in $\mathrm{R}$ 3.0.2 software (R Development Core Team 2013: [27]). Oneway ANOVA and Tukey's multiple comparison tests were performed to compare the effect of TCM on gene expression of the estrogen receptor versus E2 and a control. Statistical significance was set at 5\%.

\section{Results}

In order to evaluate the estrogenic activity of the TCM, we used previously established reporter cell lines [25,28]. These cell lines, which expressed ER $\alpha, E R \beta$ or these receptors deleted of their $\mathrm{A} / \mathrm{B}$ region $(\triangle \mathrm{A} / \mathrm{BER} \alpha, \Delta \mathrm{A} / \mathrm{BER} \beta)$, allowed characterization of ER specificity (between ER $\alpha$
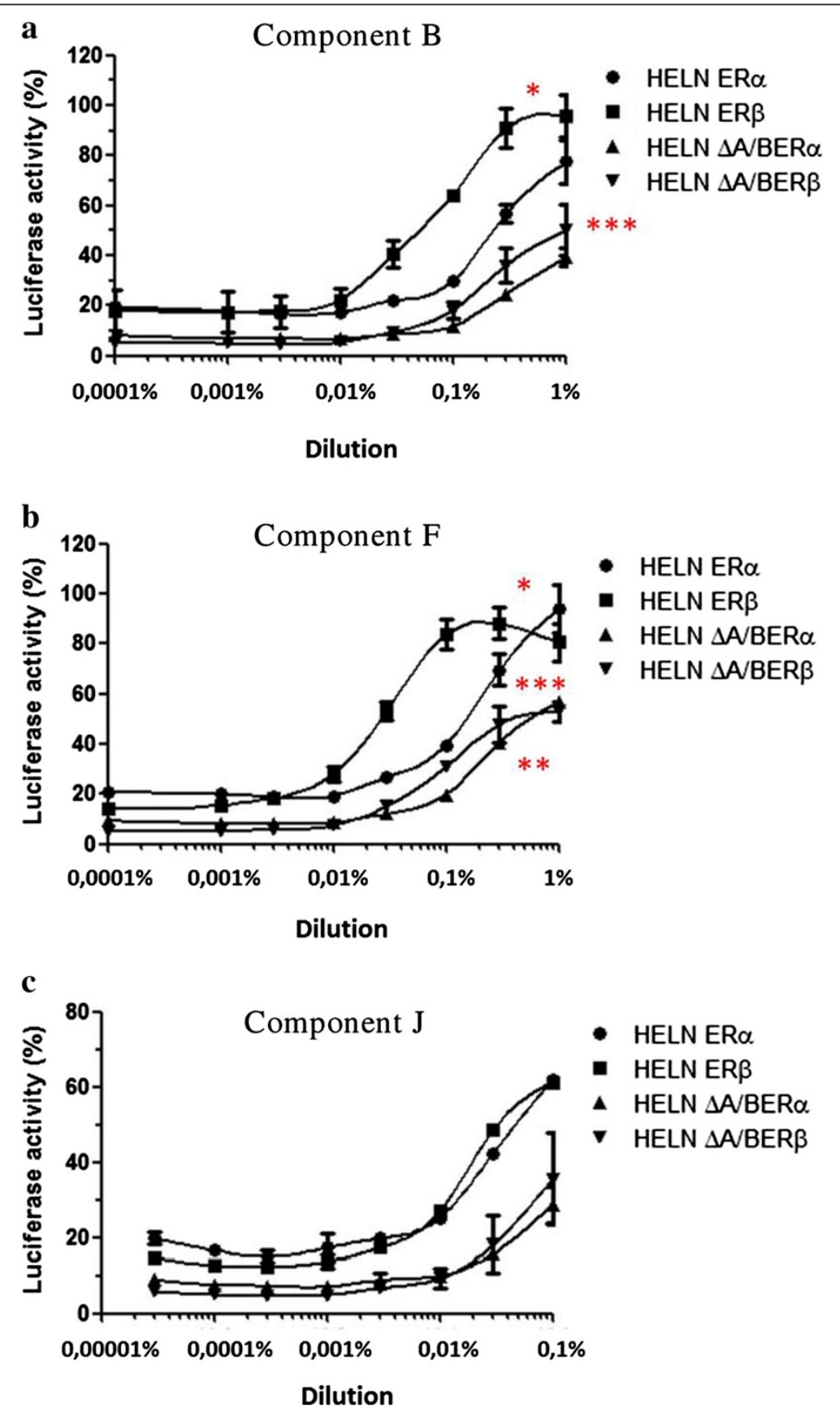

Figure 3 The dilution-response curves to components B, F, J. The curves were constructed by exposing HELN-ERa (ERa), HELN-ERß (ERß), HELN-DA/BERa (DAB-ERa), and HELN-DA/BERß (DAB-ERß) cells to increasing dilutions of ingredient B (a), F (b), J (c) of the TCM for 16 hours at $37^{\circ} \mathrm{C}$ in a $5 \% \mathrm{CO}_{2}$ humidified atmosphere. The results are expressed as a percentage of maximum luciferase activity (100\%), which was determined when the cells were exposed to $10^{-8} \mathrm{ME}_{2}$. Each value at each dilution in the response curves is the mean \pm standard deviation from three separate experiments. $p<0.05:{ }^{*}=E C_{50}$ ERa vs $E R \beta,{ }^{* *}=$ Max. luciferase activity ERa vs $\triangle A / B E R a,{ }^{* * *}=$ Max luciferase activity ER $\beta$ vs $\triangle A / B$ ER $\beta$. 
and ER $\beta$ ) and activity (antagonism, partial or full agonism). Before assessing the estrogenic activity of the herbal medicine, we used these cell lines to characterize two phytoestrogens, genistein and ferutinin, in comparison with the ER natural ligand, estradiol. Substantial differences in maximal activities and $\mathrm{EC}_{50} \mathrm{~S}$ were detected in the concentration-response curves for $E_{2}$ (Figure 1a) and the phytoestrogens genistein (Figure $1 \mathrm{~b}$ ) and ferutinin (Figure 1c). The $\mathrm{EC}_{50} \mathrm{~S}$ for $\mathrm{E}_{2}$ in the HELN-ER $\alpha$, HELN-ER $\beta$, HELN- $\triangle \mathrm{A} / \mathrm{BER} \alpha$, and HELN- $\triangle \mathrm{A} / \mathrm{BER} \beta$ cell lines were $0.017 \mathrm{nM}, 0.068 \mathrm{nM}, 0.034 \mathrm{nM}$, and $0.22 \mathrm{nM}$, respectively, and these values are in agreement with previously reported values $[25,28]$. The $\mathrm{EC}_{50}$ of $\mathrm{ER} \alpha$ for genistein was higher than that of ER $\beta$ (Figure $1 \mathrm{~b}$ and

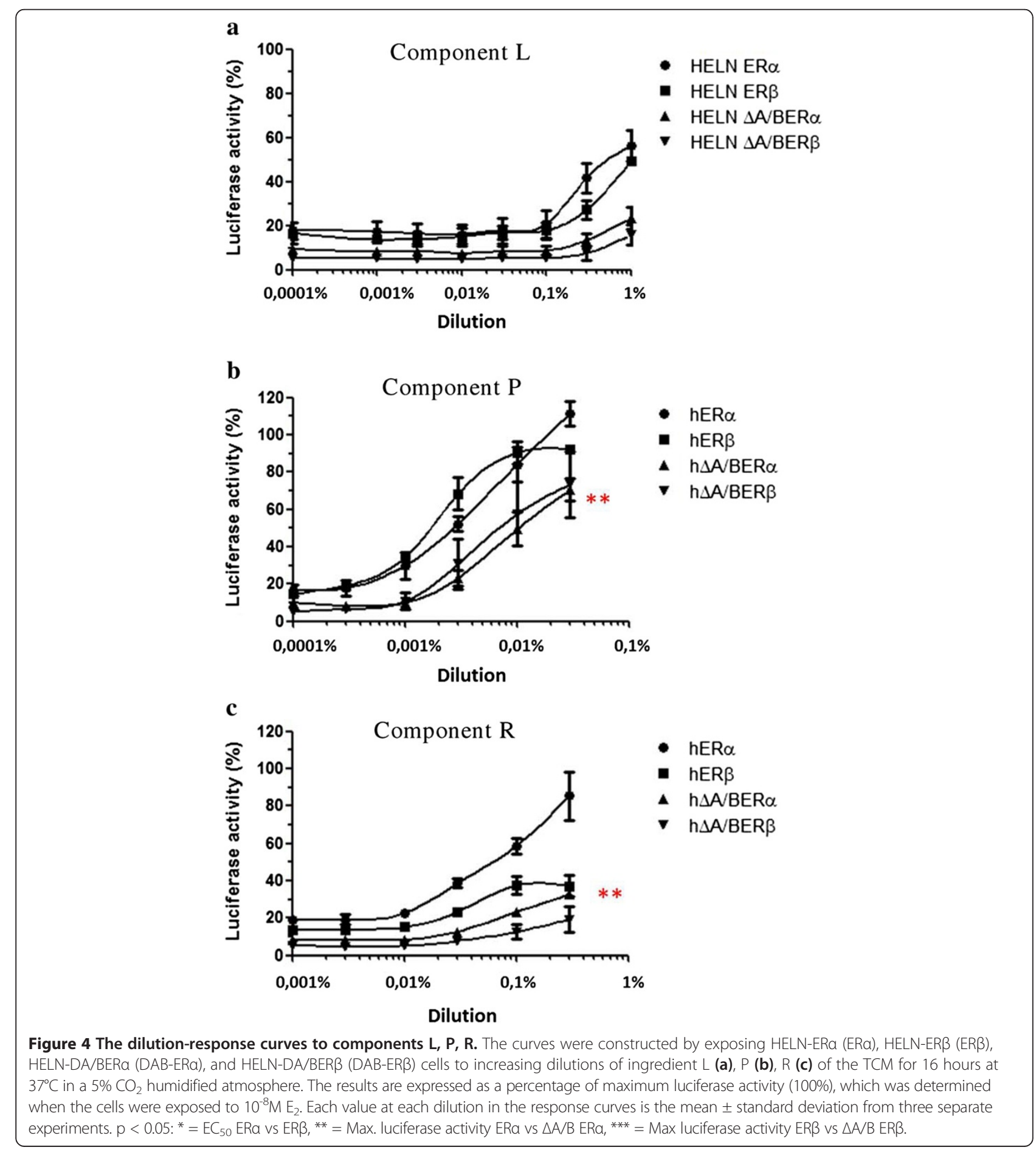


Table 3), and this was due to its better affinity for ER $\beta$ than ER $\alpha$ [28]. Interestingly, deletion of the N-terminal $A / B$ domain of ER $\beta$ had a partial effect on genistein's transactivation efficacy (115.6 and $77.6 \%$ of maximal activity for $E R \beta$ and $\triangle A / B E R \beta$, respectively) (Table 4 ), which confirms previously published findings that genistein is a partial ER $\beta$ agonist [29,30]. Ferutinin appeared to be a full ER $\alpha$ agonist and a partial ER $\beta$ agonist (99.1 and
$38.8 \%$ of maximal activity for ER $\alpha$ and $E R \beta$, respectively) (Table 4). Moreover, ferutinin lost its partial activity when the $\mathrm{N}$-terminal A/B domain of ER $\beta$ was deleted (Figure 1c).

We then tested the estrogenic activity of the TCM and its 18 components. The $\mathrm{EC}_{50} \mathrm{~s}$ for ER $\alpha$ and $\mathrm{ER} \beta$ and the maximal activity are summarized in Tables 3,4 and 5 . The $\mathrm{EC}_{50}$ for $\mathrm{ER} \beta$ of the TCM was slightly lower than
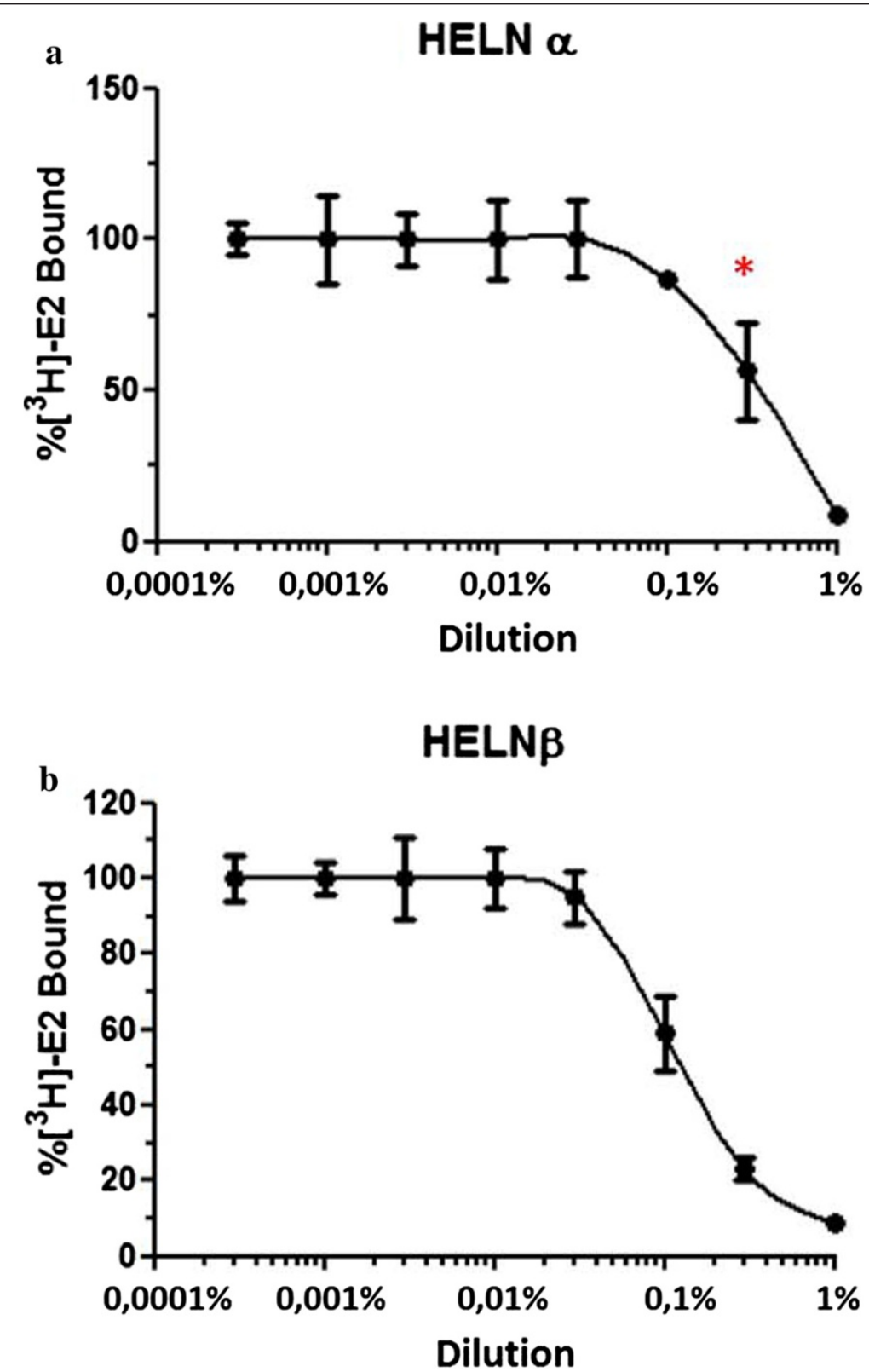

Figure 5 The effect of the traditional herbal medicine (TCM) on $E_{2}$ binding to estrogen receptor (ER)a and ER $\beta$. The competition binding curves for ERa (a) and ERß (b) were generated by exposing HELN-ERa and HELN-ERß cells, respectively, to increasing dilutions of the TCM (1\%-0.0003\%) in the presence of radiolabeled $17 \beta$-estradiol $\left(\mathrm{E}_{2}\right)\left(0.3 \mathrm{nM}\left[{ }^{3} \mathrm{H}\right]-\mathrm{E}_{2}\right)$ for 3 hours at $37^{\circ} \mathrm{C}$ in a $5 \% \mathrm{CO}_{2}$ humidified atmosphere. The amount of binding was expressed as a percentage of the maximum ER binding (100\%), which was defined when the cells were exposed to $100 \mathrm{nM}$ unlabeled $\mathrm{E}_{2}$. The $I C_{50}$ value was defined as the dilution at which $E_{2}$ binding was $50 \%$. Each value at each dilution in the binding curves is the mean of duplicate determination \pm standard deviation from three separate experiments. ${ }^{*}=p<0.05$ for $I C_{50}$ ERa vs ERß. 
that of ER $\alpha(0.015 \%$ versus $0.035 \%)(\mathrm{p}=0.015)$. All the 18 components were found to have estrogenic activity and we were able to determine the $\mathrm{EC}_{50} \mathrm{~s}$ for $\mathrm{ER} \alpha$ and ER $\beta$ s for eight components, namely B, F, I, J, L, M, P, and $\mathrm{R}$ (Table 5). The $\mathrm{EC}_{50} \mathrm{~s}$ for ER $\beta$ of the TCM and four of its components, I, J, P, and R, were slightly lower than those for $\mathrm{ER} \alpha$, but not significantly at the $5 \%$ significance level. The $\mathrm{EC}_{50} \mathrm{~S}$ of two components for $\mathrm{ER} \beta$ (B and $\mathrm{F}$ ) were significantly lower than those for $E R \alpha(p=0.003$ and $\mathrm{p}<0.001$, respectively). The $E_{50} \mathrm{~s}$ for $E R \alpha$ and $E R \beta$ of the remaining two components, $\mathrm{L}$, and $\mathrm{M}$, were very similar (Table 3).

The HELN- $\triangle \mathrm{A} / \mathrm{BER} \alpha$ and HELN- $\triangle \mathrm{A} / \mathrm{BER} \beta$ cell lines were then used to further characterize the agonistic properties of the TCM and six of the eight components, which presented the maximal transcriptional activity on ERs (Table 4, Figures 2, 3 and 4). We found that the maximal activity values of the TCM and the six selected components in the HELN- $\triangle \mathrm{A} / \mathrm{BER} \beta$ and HELN- $\triangle \mathrm{A} / \mathrm{BER} \alpha$ cells were always lower than those found in the HELN-ER $\alpha$ and HELN-ER $\beta$ cells (Table 4). For example, we found that the maximal activity of the TCM in the HELN-ER $\alpha$ cells was $107.4 \%$ versus $58 \%(p=0.014)$ in the HELN- $\triangle \mathrm{A} / \mathrm{BER} \alpha$ cells. This finding was confirmed in HELN-ER $\beta$ and HELN- $\triangle \mathrm{A} / \mathrm{BER} \beta$ cells: the maximal activity of the TCM in the HELN-ER $\beta$ cells was $78 \%$ versus $56 \%(p=0.026)$ in the HELN- $\triangle \mathrm{A} / \mathrm{BER} \beta$ cells. This result suggests that the TCM and the six selected components have partial ER agonist activity.

We then characterized the estrogenic activity of the TCM. Whole-cell ER competitive binding assays using $\left[{ }^{3} \mathrm{H}\right]$ E2 binding to ER $\alpha$ and ER $\beta$ were then done in order to confirm that the ER activity of the TCM is achieved by binding to $\mathrm{ER} \alpha$ and $\mathrm{ER} \beta$. The $\mathrm{IC}_{50}$ for $\mathrm{ER} \beta$ of the TCM was $0.1 \%$ and this value was slightly lower than its $\mathrm{IC}_{50}$ for $\mathrm{ER} \alpha, 0.3 \%(\mathrm{p}<0.05)$. This finding also confirms that the binding affinity for ER $\beta$ of the TCM was slightly greater than that for ER $\alpha$ (Figure 5).

We then determined whether the TCM was able to activate endogenous E2-regulated genes in the $\mathrm{ER}^{+}$ breast cancer cell line MCF-7. For HELN cell proliferation, we first found that the medicine acted as a full agonist on cell growth and that cell proliferation began to be activated at $0.003 \%$ (Figure 6). We also found that the TCM medicine was able to activate the expression of the endogenous $\mathrm{E}_{2}$-regulated genes, namely pS2, PR, RIP140, RAR $\alpha$, and GREB1 (Figure 7). This was statistically significant at the $5 \%$ significance level for $\mathrm{pS} 2$, RIP140 and RAR $\alpha$.

\section{Discussion}

The billowing use of alternative medicines and in particular herbal products and TCMs by adults and children [31] is based on the popular belief that these products are "harmless." Based on the knowledge that there are numerous estrogens with varying degrees of selectivity for ER $\alpha$ and ER $\beta$ in many TCMs [14], we hypothesized that the TCM, which was prescribed by a naturopath to a short-statured 4-year-old boy with multiple pituitary hormone deficiencies, would contain components with potent estrogen activity and would be responsible for the child's growth acceleration and bone maturation.

In order to test this hypothesis, we investigated the estrogenic activity of the TCM and its 18 components in a chemistry-focused study and a target-directed study. In the chemistry-focused study, we investigated the estrogenic activity of the TCM and its 18 components and found that the TCM and its components possess partial ER $\beta$ and ER $\alpha$ agonist activity with a slightly higher affinity for ER $\beta$. In the target-directed study, we investigated the mechanism of action of the TCM constituents using reporter HELN-ER $\beta$ and ER $\alpha$-positive
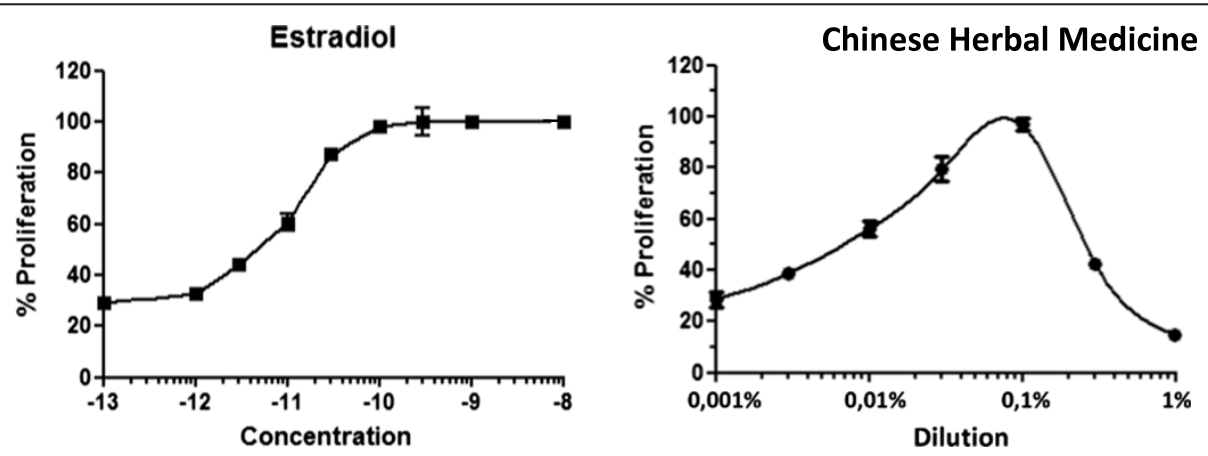

Figure 6 The proliferative response of MELN cells to the traditional Chinese medicine (TCM). The proliferation curves were generated by exposing HELN cells to increasing concentrations of $\mathrm{E}_{2}\left(10^{-13} \mathrm{M}-10^{-8} \mathrm{M}\right)$ and increasing dilutions of the TCM $(1 \%-0.001 \%)$ for 10 days, and then to the vital mitochondrial dye, 3-[4,5-dimethyliazol-2-yl]-2,5-diphenyltetrazolium bromide (MTT), for four hours at $37^{\circ} \mathrm{C}$ in a $5 \% \mathrm{CO}_{2}$ humidified atmosphere. The data are expressed as a percentage of the maximum proliferation (100\%), which was defined as the amount of proliferation when the cells were exposed to $10^{-8} \mathrm{M} 17 \beta$-estradiol. Each value at each concentration or dilution in the curves is the mean of quadruplicate determinations \pm standard deviation from three separate experiments. 

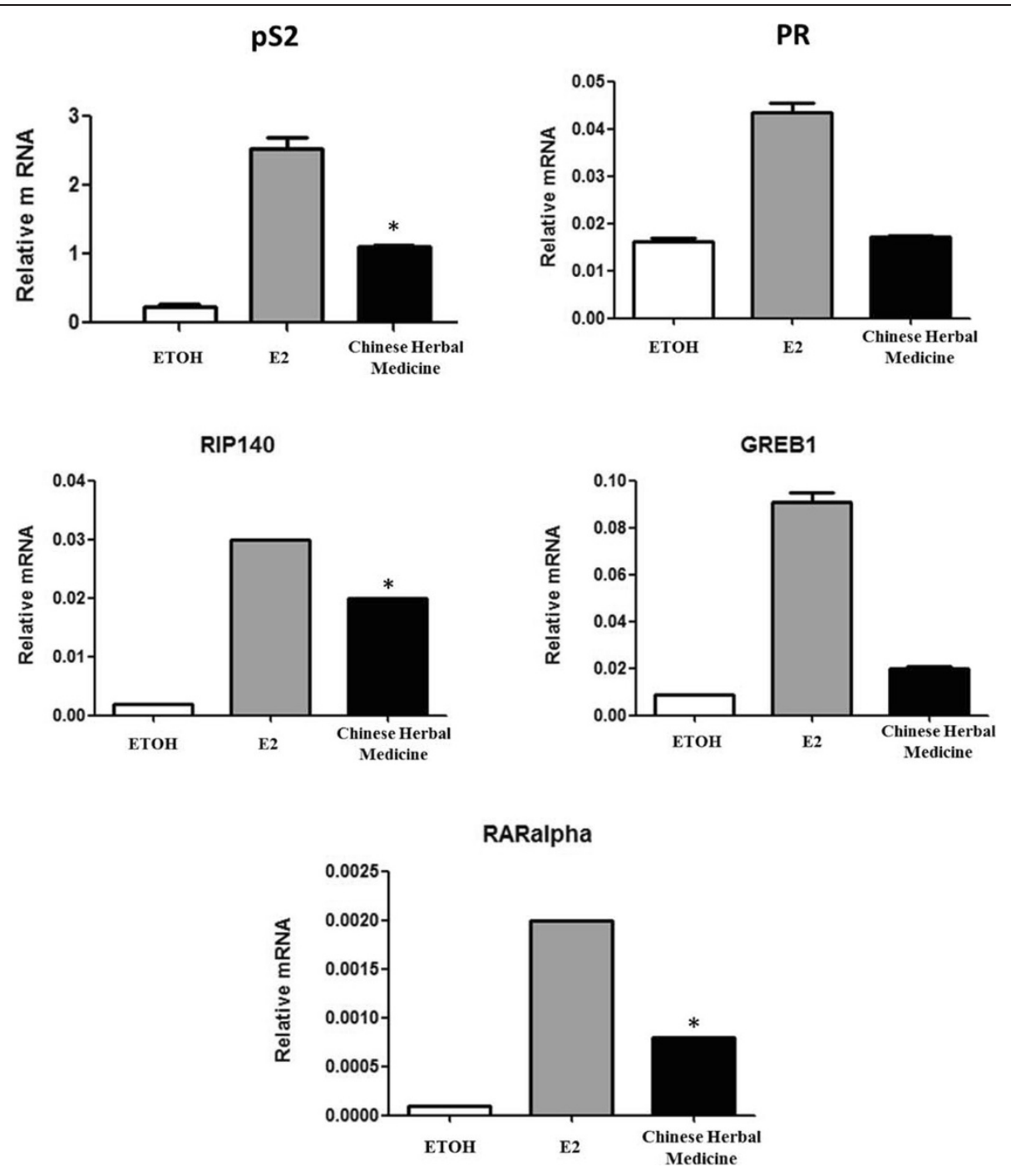

Figure 7 The effect of the traditional Chinese medicine (TCM) on gene expression of the estrogen receptor. MELN cells were treated for 24 hours at $37^{\circ} \mathrm{C}$ in a $5 \% \mathrm{CO}_{2}$ humidified atmosphere with either $10^{-8} \mathrm{M} 17 \beta$-estradiol $\left(\mathrm{E}_{2}\right)$ or a $0.3 \%$ dilution of the TCM. At the end of the incubation, the mRNA expression levels of five endogenous $E_{2}$-regulated genes, pS2, the progesterone receptor (PR), RIP140, GREB1, and RARa, were determined by quantitative real-time polymerase reaction. The expression levels of each gene were normalized to that of the housekeeping 285 gene, and quantified in relative units using qBase ${ }^{\text {PLUS }}$ [26]. Data are displayed as the average of two determinations \pm standard error of the mean. ${ }^{*}=p<0.05$ vs ETOH.

cell lines and confirmed partial estrogenic activity using whole-cell competitive binding, cell proliferation, and endogenous gene expression assays. From these results, we have concluded that the TCM contains compounds that could be considered to be potential selective estrogen receptor modulators (SERMs) with specific agonist estrogenic activity.

A recent work demonstrated the stimulating action of a phyto-SERM, resveratrol, on growth plate cartilage [32]. This phyto-SERM displayed $E_{2}$ antagonist activity for ER $\alpha$ with selected EREs and agonist activity for ER $\beta$ [33]. In rabbits, resveratrol improves both axial and appendicular bone growth without altering the serum insulin-like growth factor-1 (IGF-1) level [32]. Nevertheless, ER $\alpha$ and ER $\beta$ (activity) may also have a direct action on IGF-1 gene expression [34] and IGF-1-induced responses [35]. It is thus possible that the estrogenic actions of some of the TCM components influenced the serum IGF-1 levels in our study patient.

Did we prove this hypothesis in this bedside-to-bench study? We found that the TCM and some of its components have ER $\alpha$ and ER $\beta$ selectivity and partial estrogen agonism. Accordingly, we concluded that the complex estrogenic activity of this TCM was due to the presence of ingredients with estrogenic activity that are able to sustain bone growth and maturation without affecting 
other estrogen-dependent tissues. The well-known dominant negative effect of $E R \beta$ on $E R \alpha$, as well as the partial and AF-1-dependent agonist activity of the TCM, may explain the absence of breast development in this patient [36].

\section{Conclusions}

This study has several limitations. The first limitation is the dilution of the phytoestrogens in the various assays that were used to establish the pharmacological profile for the estrogenic activity of the TCM and the resultant circulating phytoestrogen levels in the patient. The TCM was taken orally by the patient, and we can assume that the serum and/or tissue concentrations of the TCM and its constituents would be lower than those in the TCM. Although we investigated a range of dilutions of the TCM and its constituents, we found that six of these components have partial estrogenic activity. The exact phytochemical and pharmacological profiles of the components are still unknown, and many drugs are converted to metabolites that retain the intrinsic activity of the parent drug. This lack of knowledge is a second limitation of our study. We are not aware of any studies in which a phytochemical profile of the ingredients in the TCM has been correlated with an in vitro and/or in vivo pharmacodynamic profile for phytoestogenic activity or a pharmacokinetic profile for the parent ingredients and their metabolites. The third limitation of our study is the quality and/or purity of the medicine's components and the method of preparing the TCM. In this bedside-to-bench study, we found that the TCM and some of the components had varying estrogenic activity and potency over a large dilution range. Finally, we did not use cultured osteoblasts to investigate the estrogenic activity and mechanism of action of the TCM and its 18 components. Although it is tempting to conclude that the complex estrogenic activity of the TCM that was given to our patient accounted for unexpected growth acceleration and rapid bone maturation without any untoward effects on the development of his breast and genitals, the finding of accelerated growth velocity after ingestion of the TCM could be viewed as coincidental because the TCM is a non-standardized mixture of 18 components and causality cannot be unequivocally proved. Although the presence of evidence is not always evidence of causality, the challenge now is to identify those constituents in the TCM that may be therapeutically beneficial for growth-deficient children and then to develop them as therapeutic agents for these individuals.

\section{Competing interests}

The authors declare that they have no competing interests.

\section{Authors' contributions}

DT and ZH followed the patient and participated in writing the manuscript. CS conceived the study and draft the manuscript. FP conceived the study, carried out the estrogenic activity evaluation, participated in the various other assays and drafted the manuscript. MG carried out competitive binding, proliferation and gene expression assays. NS participated in estrogenic activity evaluation. PB designed the cell lines and framed the various assays. VG performed the statistical analysis. All authors read and approved the final manuscript.

\section{Acknowledgements}

The authors wish to thank Dr. Arieh Bomzon for his editorial assistance in preparing the manuscript.

\section{Author details}

'Pediatric Endocrinology, Meyer Children's Hospital, Rambam Medical Center, Ruth and Bruce Rappaport Family Faculty of Medicine, Technion-Israel Institute of Technology, Haifa 31096, Israel. ${ }^{2}$ Unité d'Endocrinologie Pédiatrique, CHU Arnaud de Villeneuve, Montpellier, France. ${ }^{3}$ Département d'Hormonologie, CHU Lapeyronie, et Université Montpellier 1, Montpellier, France. ${ }^{4}$ INSERM U896, IRCM, Montpellier F-34298, France. ${ }^{5}$ Rappaport Family Institute for Research in the Medical Sciences, Haifa 31096, Israel.

${ }^{6}$ Département de I'Information Médicale, CHU Montpellier, Montpellier, France.

Received: 11 May 2014 Accepted: 7 September 2014

Published: 10 October 2014

\section{References}

1. Davidson P, Hancock K, Leung D, Ang E, Chang E, Thompson DR, Daly J: Traditional Chinese Medicine and heart disease: what does Western medicine and nursing science know about it? Eur J Cardiovasc Nurs 2003, 2:171-181.

2. Huang CF, Lin SS, Liao PH, Young SC, Yang CC: The immunopharmaceutical effects and mechanisms of herb medicine. Cell Mol Immunol 2008, 5:23-31.

3. Peng A, Gu Y, Lin SY: Herbal treatment for renal diseases. Ann Acad Med Singapore 2005, 34:44-51.

4. Stickel F, Schuppan D: Herbal medicine in the treatment of liver diseases. Dig Liver Dis 2007, 39:293-304.

5. Tillisch K: Complementary and alternative medicine for gastrointestinal disorders. Clin Med 2007, 7:224-227.

6. Farnsworth NR, Krause EC, Bolton JL, Pauli GF, van Breemen RB, Graham JG: The University of Illinois at Chicago/National Institutes of Health Center for botanical dietary supplements research for women's health: from plant to clinical use. Am J Clin Nutr 2008, 87:504S-508S.

7. Chagin AS, Savendahl L: Oestrogen receptors and linear bone growth. Acta Paediatr 2007, 96:1275-1279.

8. Smith EP, Boyd J, Frank GR, Takahashi H, Cohen RM, Specker B, Williams TC, Lubahn DB, Korach KS: Estrogen resistance caused by a mutation in the estrogen-receptor gene in a man. N Engl J Med 1994, 331:1056-1061.

9. Chagin AS, Chrysis D, Takigawa M, Ritzen EM, Savendahl L: Locally produced estrogen promotes fetal rat metatarsal bone growth; an effect mediated through increased chondrocyte proliferation and decreased apoptosis. J Endocrinol 2006, 188:193-203.

10. Morishima A, Grumbach MM, Simpson ER, Fisher C, Qin K: Aromatase deficiency in male and female siblings caused by a novel mutation and the physiological role of estrogens. J Clin Endocrinol Metab 1995, 80:3689-3698.

11. Rochira V, Carani C: Aromatase deficiency in men: a clinical perspective. Nat Rev Endocrinol 2009, 5:559-568.

12. Attie KM, Ramirez NR, Conte FA, Kaplan SL, Grumbach MM: The pubertal growth spurt in eight patients with true precocious puberty and growth hormone deficiency: evidence for a direct role of sex steroids. J Clin Endocrinol Metab 1990, 71:975-983.

13. Simm PJ, Bajpai A, Russo VC, Werther GA: Estrogens and growth. Pediatr Endocrinol Rev 2008, 6:32-41.

14. Koehler KF, Helguero LA, Haldosen LA, Warner M, Gustafsson JA: Reflections on the discovery and significance of estrogen receptor beta. Endocr Rev 2005, 26:465-478.

15. Nilsson O, Chrysis D, Pajulo O, Boman A, Holst M, Rubinstein J, Martin Ritzen E, Savendahl L: Localization of estrogen receptors-alpha and -beta and androgen receptor in the human growth plate at different pubertal stages. J Endocrinol 2003, 177:319-326. 
16. Tora L, White J, Brou C, Tasset D, Webster N, Scheer E, Chambon P: The human estrogen receptor has two independent nonacidic transcriptional activation functions. Cell 1989, 59:477-487.

17. Benecke A, Chambon P, Gronemeyer H: Synergy between estrogen receptor alpha activation functions AF1 and AF2 mediated by transcription intermediary factor TIF2. EMBO Rep 2000, 1:151-157.

18. Berry M, Metzger $D$, Chambon P: Role of the two activating domains of the oestrogen receptor in the cell-type and promoter-context dependent agonistic activity of the anti-oestrogen 4-hydroxytamoxifen. EMBO J 1990, 9:2811-2818.

19. Mclnerney EM, Katzenellenbogen BS: Different regions in activation function-1 of the human estrogen receptor required for antiestrogenand estradiol-dependent transcription activation. J Biol Chem 1996, 271:24172-24178.

20. Borjesson AE, Windahl SH, Karimian E, Eriksson EE, Lagerquist MK, Engdahl C, Antal MC, Krust A, Chambon P, Savendahl L, Ohlsson C: The role of estrogen receptor-alpha and its activation function-1 for growth plate closure in female mice. Am J Physiol Endocrinol Metab 2012, 302:E1381-E1389.

21. Emons J, Chagin AS, Savendahl L, Karperien M, Wit JM: Mechanisms of growth plate maturation and epiphyseal fusion. Horm Res Paediatr 2011 75:383-391.

22. Sims NA, Dupont S, Krust A, Clement-Lacroix P, Minet D, Resche-Rigon M, Gaillard-Kelly M, Baron R: Deletion of estrogen receptors reveals a regulatory role for estrogen receptors-beta in bone remodeling in females but not in males. Bone 2002, 30:18-25.

23. Vidal O, Lindberg MK, Hollberg K, Baylink DJ, Andersson G, Lubahn DB, Mohan S, Gustafsson JA, Ohlsson C: Estrogen receptor specificity in the regulation of skeletal growth and maturation in male mice. Proc Natl Acad Sci U S A 2000, 97:5474-5479.

24. Windahl SH, Vidal O, Andersson G, Gustafsson JA, Ohlsson C: Increased cortical bone mineral content but unchanged trabecular bone mineral density in female ERbeta(-/-) mice. J Clin Invest 1999, 104:895-901.

25. Molina-Molina JM, Escande A, Pillon A, Gomez E, Pakdel F, Cavailles V, Olea $\mathrm{N}$, Ait-Aissa S, Balaguer P: Profiling of benzophenone derivatives using fish and human estrogen receptor-specific in vitro bioassays. Toxicol Appl Pharmacol 2008, 232:384-395.

26. http://www.qbaseplus.com

27. http://www.R-project.org/.

28. Escande A, Pillon A, Servant N, Cravedi JP, Larrea F, Muhn P, Nicolas JC, Cavailles V, Balaguer P: Evaluation of ligand selectivity using reporter cell lines stably expressing estrogen receptor alpha or beta. Biochem Pharmacol 2006, 71:1459-1469.

29. Barkhem T, Carlsson B, Nilsson Y, Enmark E, Gustafsson J, Nilsson S: Differential response of estrogen receptor alpha and estrogen receptor beta to partial estrogen agonists/antagonists. Mol Pharmacol 1998, 54:105-112.

30. Pike AC, Brzozowski AM, Hubbard RE, Bonn T, Thorsell AG, Engstrom O, Ljunggren J, Gustafsson JA, Carlquist M: Structure of the ligand-binding domain of oestrogen receptor beta in the presence of a partial agonist and a full antagonist. EMBO J 1999, 18:4608-4618.

31. Barnes PM, Bloom B, Nahin RL: Complementary and alternative medicine use among adults and children: United States. Natl Health Stat Report 2007, 2008:1-23.

32. Karimian E: Effect of selective estrogen receptor modulators (SERMs) on growth plate cartilage. In Department of Women's and Children's Health. Stockolm, Sweden: Karolinska Institute; 2010

33. Bowers JL, Tyulmenkov W, Jernigan SC, Klinge CM: Resveratrol acts as a mixed agonist/antagonist for estrogen receptors alpha and beta. Endocrinology 2000, 141:3657-3667.

34. Venken K, Schuit F, Van Lommel L, Tsukamoto K, Kopchick JJ, Coschigano K, Ohlsson C, Moverare S, Boonen S, Bouillon R, Vanderschueren D: Growth without growth hormone receptor: estradiol is a major growth hormone-independent regulator of hepatic IGF-I synthesis. J Bone Miner Res 2005, 20:2138-2149.
35. Zhang S, Li X, Burghardt R, Smith R 3rd, Safe SH: Role of estrogen receptor (ER) alpha in insulin-like growth factor (IGF)-l-induced responses in MCF-7 breast cancer cells. J Mol Endocrinol 2005, 35:433-447.

36. Lindberg MK, Moverare S, Skrtic S, Gao H, Dahlman-Wright K, Gustafsson JA, Ohlsson C: Estrogen receptor (ER)-beta reduces ERalpha-regulated gene transcription, supporting a "ying yang" relationship between ERalpha and ERbeta in mice. Mol Endocrinol 2003, 17:203-208.

doi:10.1186/1477-7827-12-97

Cite this article as: Tiosano et al:: Evidence of ERalpha and ERbeta selectivity and partial estrogen agonism in traditional Chinese medicine. Reproductive Biology and Endocrinology 2014 12:97.

\section{Submit your next manuscript to BioMed Central and take full advantage of:}

- Convenient online submission

- Thorough peer review

- No space constraints or color figure charges

- Immediate publication on acceptance

- Inclusion in PubMed, CAS, Scopus and Google Scholar

- Research which is freely available for redistribution

Submit your manuscript at www.biomedcentral.com/submit
C BioMed Central 